\title{
The Condition of a Modern University - Is There a Problem?
}

\author{
Wiktor Możgin \\ Ph.D. Student, Jagiellonian University in Kraków (Kraków, Poland) \\ E-mail: viktor1990@wp.pl \\ https://orcid.org/0000-0001-5744-8103
}

The beginning of the $21^{\text {st }}$ century became the time of the fall of the traditional idea of the university's functioning. The roots of this phenomenon could be seen in the 1960s when the paradigm of science changed. A commonly held attitude to university education changed to instrumental. Pragmatic use of acquired knowledge has become a reference point for many learners. The idea of the university, which was formed at the beginning of the $19^{\text {th }}$ century in Germany by Wilhelm von Humboldt, and then in England by the rector of the Dublin University John Newman, is now collapsing. Despite the preoccupation of the main postulates with these differing visions of the functioning of the university, today the term "university spirit" whose main goal should be to seek the truth seems not to be relevant any more. Nowadays people become more pragmatic and mostly consider the university to be only the next level of his professional career. Nowadays, we have a race for a better future, but we should not forget that the university that determines this future is the driving force behind it.

Keywords: idea of the university; collapse of modern universities; low quality of teaching; didactic university; research university; university spirit

Received: December 29, 2018; accepted: January 30, 2019

Future Human Image, Volume 11, 2019: 56-65.

https://doi.org/10.29202/fhi/11/6

\section{Introduction}

The university is an institution that undergoes permanent changes. The tendency of this changeability and the process of adjusting to the environment in which the university functions are visible from the very beginning of the university's establishment as an institution. It is important that not only the institutional essence of the university changes but also the processual idea of its functioning.

Over the course of history, two fundamental ideas of the university's functioning have been formed. The first one understands the university as a didactic-research institution whose main purpose is to seek the truth. This type of university dates back to the roots of the ancient Platonic Academy, where the basis of teaching was the sense of community, the search for the

(C) Możgin, Wiktor, 2019 
truth on the path of philosophical inquiry, and the belief that discourse is the basic method in the teaching process [Kobylarek, 2002: 90-91]. The university's didactic and research concept was later developed by Wilhelm von Humboldt. It was the basis of teaching in the $19^{\text {th }}$ and early $20^{\text {th }}$ centuries [Sauerland, 2006: 89].

The second idea of the university functioning is to treat this institution as a vocational school. The term "vocational school" is understood in this context as an institution whose main purpose is to learn a particular profession and not to seek the truth. This is a very general statement used to signal the existing dichotomy in the university's functioning process.

The origins of this kind of universities can be seen already in the Middle Ages, and their prosperity in the times of the Napoleonic University. For the French model, because this name assumed this type of university at the turn of the $18^{\text {th }}$ and the $19^{\text {th }}$ centuries, the process of preparing a state civil servant or teacher in a state school was a characteristic feature [Kobylarek, 2002: 91]. The main determinant of this kind of university was pragmatism. It was to bring tangible benefits to all those who were involved in the education process.

The basis for the functioning of both medieval and Napoleonic universities were the assumptions of the ancient school based on the transfer of knowledge. Therefore, it is impossible to speak of an explicit division of these two types of ideas. The difference, however, is in pragmatism and the way of functional use of the acquired knowledge.

The change of direction in perceiving the essence of the university took place in the nineteenth century in Germany and England due to a discussion that flared between ideas promoted by the then minister of education of Prussian Wilhelm von Humboldt and Dublin's cardinal John Henri Newman. At this point, one should stop the divagations concerning this episode in the development of higher education, because it will be discussed in more detail later in this article. It is the basis for reflection on the essence of the modern university and therefore deserves a more extensive discussion.

The existence of an ideological dichotomy in the process of university functioning is the background of reflections on the face of the modern university. The second half of the twentieth century is a time of questioning the fundamental ideas of the university's activities as a teaching and research institution. The tendency of university collapse is related to the cultural and social context, as the value of the scientific research method and the validity of knowledge and science was increasingly questioned [Kobylarek, 2002: 90]. An important aspect was also the mentioned pragmatism consisting of using the acquired knowledge. The manifestation of this pragmatism is, on the one hand, a learned specialist, and on the other, as John Newman described it - an intellectual or a gentleman.

The problem regarding the fall of the university, whose most important manifestation is the departure from the basic idea of teaching and research work and the search for the truth, has its cultural, political and socio-economic background. In 1959, Charles P. Snow published the book The Two Cultures and the Scientific Revolution. The main thesis put forward by the author was the statement that from the late nineteenth and the second half of the twentieth century there was a distance between a culture based on humanistic values and science based on cognitive values. This phenomenon played a negative role in the process of social development. That is why the question arose, what next? The overcoming of this conflict was the emergence of the "third culture". However, how did the emergence of a new cultural sphere take its toll on the development of higher education and the shaping of the university's idea?

It is possible to carry out a parallel here, which will refer, on the one hand, to the dichotomy on which this "third culture" is based, and, on the other hand, to the dichotomy of the 
ideological functioning of the university, that is, its pragmatic and intellectual nature. The theorem about the similarity of these processes and their connection could be questioned, but the contextual character of the "third culture" fits perfectly into the trend of transformations that the university in the second half of the twentieth century. John Brockman points out that the "third culture" is the dominance of the new paradigm of the world of science. It is a conflict between representatives of the humanities and scholars, thinkers and researchers in the empirical world who, thanks to their work, take over the role of the traditional intellectual elite [Brockman, 1996: 23-25].

The cultural paradigm has changed, as well as the idea of university functioning. The world of science has become more accessible to ordinary people. This is one of the main assumptions of the "third culture". The hermetic nature and the apotheosis of failure to adjust to the prevailing conditions of socio-economic educational processes contributed to the reevaluation of the university's idea. The university has become an institution that teaches in a very accessible way a particular profession or speciality. Education is becoming more and more common and loses its elitist character. Nowadays, a factory worker does not have to know the most outstanding German thinkers of the $19^{\text {th }}$ century, to enjoy a high social position and to achieve the intended professional goal, along with economic success. Man becomes a philistine, for whom the world of science is limited to acquiring proper production skills.

For decades, the scientific community has struggled to overcome this problem, which is deeply rooted in society itself. This problem has connotations of both a political nature because each teaching system functions in a specific framework imposed by the state; cultural nature, because the culture of a given country is a sphere in which science functions; and socioeconomic nature, an exemplification of which is the position occupied by a man in society. In connection with the presented tendency of the transformation of the idea and the essence of the university's operation, the purpose of this article is to try to answer one fundamental question: what should a university in the modern world be like?

\section{The idea of Wilhelm von Humboldt University}

In 1807, the then King of Prussia, Frederick William III, declared that he agreed to establish a universal university in Berlin, which was defined as a self-governing and autonomous academic institution, which is excluded from the sphere of external (political and economic) influence and internal interests. Within the university itself. This was due to the fact that links between universities and the industry and the sphere of politics were considered very suspicious at that time [Zakowicz, 2012: 62-63]. The task of establishing such an independent institution was entrusted to Wilhelm von Humboldt, who then served as the director of the Section for Art and Public Education at the Ministry of the Interior. The idea of the university, which Wilhelm von Humboldt propagated, has become one of the dominant models of higher education in nineteenth-century Europe. The Humboldt model of the university's operation was also referred to as "German" or "liberal". The basic assumption of his concept was the principle of freedom of teaching and research and the principle of combining didactic and research functions within the same unit [Sauerland, 2006: 90].

Wilhelm von Humboldt based his conception on three pillars. The first of these was the unity of education and research already mentioned; the other was the unity of knowledge; and the third - the unity of professors and students [Zakowicz, 2012: 63]. The assumptions regarding the first pillar consisted of the pursuit of the fundamental goal of teaching, namely 
the search for the truth. Therefore, in accordance with the assumptions of Wilhelm von Humboldt - this process was to be based on conducting scientific research and educating students. The exemplification of this process was to be the implementation of learners not only in theoretical assumptions but also in empiricism, which allowed practical perception of the phenomena studied. The second pillar, constituting the unity of knowledge, was based on the philosophical assumptions that individual scientific disciplines that are diverse between them make up general knowledge, which means that each of them is just as important as other [Bartnicka \& Szybik, 2005: 144-147]. In turn, the third pillar based on the assumption of the unity of professors and students is that the professor is not infallible. The professor has the knowledge, but he does not know everything, he has no monopoly on the truth. The student while in the process of discovering the truth in the relationship with the professor is on the same level. The professor and the student jointly seek to solve specific problems that constitute the essence of science [Zakowicz, 2012: 63]. Wilhelm von Humboldt pointed out that science is a collection of unresolved problems, which is a platform for cooperation between a professor and a student. He claimed that the professor would be able to find a solution to a particular problem much sooner, but regardless of this, the student learns the correct approach to problems and to learn. Searching for a solution to a specific problem requires both a professor and a student, a creative approach, which in turn contributes to the development of creativity and innovation competence. This is extremely important in the educational development process [Sauerland, 2006: 90-91].

In the introduction of the work, it was mentioned that the functioning of the university, and especially the modern university, is integrated into a specific political and socio-economic system. Wilhelm von Humboldt postulated the freedom and autonomy of the functioning of the university. It consisted primarily of the independence of professors and students from the political environment and various groups lobbying their interests in order to acquire qualified specialists in a specific field. It was a kind of objectification of the university as an institution preparing the workforce. Independence was to also affect the sphere of scientific research. They were to be conducted without political and ideological pressure, so that they were as reliable as possible and in accordance with the actual state [Zakowicz, 2012: 63-64].

Wilhelm von Humboldt believed that the basic education courses should be philology, philosophy and mathematics. Well, philology creates a sphere in which a person can deal with the text in the right way. This means that it can understand not only what is written, but also the conditions under which it was prepared. He can understand the context in which the text was created. This is related to the concept of historical understanding, which was propagated by Georg Simmel. Generally speaking, it means dealing with the text (and not only) in such a way that the psychological reality is recognized as historical [Simmel, 1993: 154-155]. This means that in order to understand the poems of Johann Wolfgang von Goethe, one must first know the "spirit of the time" prevailing when the eminent German poet created it. Therefore, the essence of philology is to illustrate the text in such categories that the reader can not only understand its content but also make it the object of appropriate intellectual reflection. Philosophy was needed in order for the above-mentioned reflection to be properly targeted and beneficial. Philosophy was closely related to the sphere of metaphysics, a sphere that goes beyond mere physicality. The intellect was the tool that was used by man to make the right reflection. Mathematics, on the other hand, gave the opportunity to formally address problems. Creating models of solutions to problems that professors and students worked on [Black, 1962: 46-51]. 
The Wilhelm von Humboldt University was an institution whose main task was to develop critical thinking and student creativity; directing them to the right path of observation and understanding of the world. Tadeusz Czeżowski claimed that a university student is in many ways similar to a self-taught student. The state of his knowledge will depend only on how much he determines himself. The University only gives direction but in no case does it constantly monitor the student's progress [Czeżowski, 1946: 28-29]. The university model initiated by Wilhelm von Humboldt played an important role in the process of shaping the idea of the contemporary university. The main task of the university as a teaching and research institution is to investigate the scientific truth. It is possible by striving for objective knowledge and improving research methods.

Being a university man means being not only part of the educational process but also being a part of society. That is why it was so important from the point of view of Wilhelm von Humboldt to raise not only intellectual but also moral values in man. It was one of the elements of the process of shaping a civil society that cares about the development of not only its own but also the entire community.

\section{The idea of the John Henry Newman University}

The idea of Wilhelm von Humboldt's university was very popular in nineteenth-century Europe. In spite of all its advantages, which contributed to the development of higher education at that time, there were voices that criticized the Humboldtian system of higher education. The prominent place in the discussion about the shape of the then university was taken by the English philosopher and theologian John Henry Newman. In 1851, he was appointed the rector of the newly created Catholic University of Dublin. With such an important function in the education system, John Newman prepared nine lectures on the organization and essence of the university [Miłek, 2009: 60-61].

In line with the assumptions of John Newman, the aim of the university is to determine the appropriate level of education and the aspiration of all learners to this level [Newman, 1990: 227]. What would be the basis of this appropriate level? Well, he would resist on two pillars intellect and truth. By perfecting the intellect, man is to improve his ability to understand and contemplate the truth [Newman, 1990: 226-227].

John Newman at the center of the educational process puts on the development of the intellect. It was the heart of all the reflections on university education. Eukasz Miłek indicates that John Newman justified the role of the intellect by referring to the dispute that took place at the beginning of the 19th century between the journalists of the Edinburgh Review and representatives of the University of Oxford. The subject of the dispute was the education program at the University of Oxford. Publishers Edinburgh Review — John Playfair, Francis Jeffrey and Sydney Smith - claimed that the criterion for good studies is their practical usefulness. On the other hand, representatives of the University of Oxford - Frederick Copleston and John Davison presented the opposite position. They believed that good studies are studies that care for the creation of the intellect, while practical utility was completely rejected by them [Miłek, 2009: 61]. John Newman strongly opted for the position represented by the Oxford people.

Frederick Copleston believed that the practical usefulness of education is related to the directing of all intellectual forces of man in one particular discipline, which gives the possibility to perform one activity. The focus on usability is positive in the context of the development of 
society, but it can have negative effects on a particular individual. Therefore, a man should take care of his own development by nurturing his intellect. According to the Coplestonian idea of science, which was undoubtedly supported by John Newman, literature plays an important role in the process of intellectual development. Literature, which did not contribute to the acquisition of certain practical skills, but had a significant impact on the expansion of mental abilities [Miłek, 2009: 62]. John Davison, whose views were also supported by John Newman, believed that man should not focus his attention on one occupation. For him, it was important for a man to develop intellectually while nurturing his culture of the intellect. An expression of such predispositions would be the ability to conduct a reliable conversation. And it is possible only when a man has a wide range of knowledge, which is based on intellectual abilities [Newman, 1990: 243-245]. In addition, not only the ability to speak is a very important element in human life, but also the ability to judge is what you cannot forget when you are thinking about the intellectual abilities of a human being.

For John Newman, knowledge is free and self-sufficient when it is philosophical knowledge. Philosophy is the basis in the process of considering what is true. Knowledge is called philosophy, or science when it is subject to the action of reason [Newman, 1990: 192-193]. According to the idea of John Newman, the University should cultivate the philosophical and scientific nucleus of knowledge, because it is a worthy undertaking both for the university as an institution and for the man himself. In addition, the university should care for the student's analytical and classification abilities. An important task is not only to provide knowledge and information about things and phenomena but also to be able to connect them in a proper way. The main goal of the university is to work on the intellect, which contributes to the good of not only the individual but also prepares him/her best to perform duties towards society. In this connection, the practical goal of university education according to John Newman is to train good members of society and serve the interests of the general good [Newman, 1990: 247-250]. According to the idea of the Newman University, the tasks of this institution are to rely on raising the intellectual level of society; setting goals for the broad masses; and facilitating the process of exercising political power [Miłek, 2009: 67-68].

John Newman criticized the then higher education system in England. He pointed to three main problem areas that contribute to lowering the level of teaching. The first is related to flooding students with an excessive amount of information. It causes a state of chaos and ignorance, which information is important and which can be rejected. The second reason for the low level of education is absorbing the mind with insignificant objects. Finally, the third area of problems concerned the issue of moderation in teaching. The university should develop such a teaching system so as not to overdo it in the information, because a detailed presentation of many things does not have a philosophical or synthetic meaning [Miłek, 2009: 68].

In conclusion, the idea of John Newman's university was based on the intellectual development of man (the education of a gentleman). Mind training overshadowed the research role of the university, which was an integral part of the Wilhelm von Humboldt model. John Newman believed that the research and teaching functions are very difficult to reconcile. That is why the university "English" completely rejected research and focused all of its strength on the education of a "gentleman" who contributes to the development of society and the state. 


\section{The idea of a modern university}

The idea of the university proposed by Wilhelm von Humboldt and John Newman played an important role in the process of shaping a modern university, which is often referred to as an institution in which both didactics and research are carried out. It is clear that the liberal idea of the university, which was formed at the beginning of the 19th century in Germany, found more supporters compared to the "English" university. However, the model proposed by Wilhelm von Humboldt nowadays goes to extremes, which manifests itself in the pragmatic approach to knowledge that is gained. There would be nothing wrong with it because pragmatism is a useful use of knowledge - which in its nature contradicts the concept promoted by John Newman. The problem lies primarily in the level of teaching, which is decreasing radically from year to year. At this point, both concepts come to a common denominator, namely - knowledge. The university's task is to transfer knowledge to students, but the degree of their involvement in the educational process is greatly diminished. Richard Arum on the example of American universities indicates that in the 1960s, students spent an average of 25 hours a week on their own work, consisting of reading, library inquiries, preparation for classes. In the twenty-first century, the amount of this time has decreased dramatically and is only 12 hours [Arum, 2011: 84-87]. Paraphrasing Wilhelm Dilthey's statement — today the "university spirit" is being lost.

The beginning of this negative tendency dates to the end of the $20^{\text {th }}$ century. Then there was a clear crisis in the idea of the university. The University's research function, promoted on a large scale by the Humboldtian idea, has been strongly criticized. It mainly concerned scientific methods whose main task was to seek the truth. The validity of knowledge and science was also questioned [Kobylarek, 2002: 96]. Karl Popper with his theory of permanent scientific revolution, Thomas Khun with the concept of a scientific paradigm and finally Paul Feyerabend and his concept of methodological anarchism have indicated that there is no one, absolutely effective method of reaching the truth. There is no one solid concept leading to the knowledge of the truth, each of them is partial [Feyerabend, 1996: 217-219]. Such views have disrupted the functioning of universities as teaching and research institutions. The resulting need to find a solution that would overcome the growing problem. The way out of this situation was to base research activity on qualitative methods.

This was not the only attempt, because the solution that would affect the increase in the level of education was the idea of creating research universities. Institutions whose main purpose is to conduct advanced scientific research and didactic activities, having a clear elite character [Rowiński et al., 2017]. In this context, a question arises regarding the independence of this type of institution from political and economic influences. There are voices claiming that the idea of research universities comes from the university model of Wilhelm von Humboldt, which combined didactics and research in one institution. The German precursor, in spite of everything, postulated the freedom of universities from the influence of the state and various types of lobbying groups. The issue of financing the activities of research universities is also essential. There is a tendency to create private research institutes owned by large multinational corporations. However, speaking of universities whose activities are financed by the budget, one can come to the conclusion that their achievements are a public good [Collini, 2012: 17-18]. At this point, there is a problem that concerns the independence of universities from the state and the economic sector. Is it still possible to refer to the traditional ideas of the university's functioning, which are based on the freedom and independence of the university as a research and teaching institution? 
The University of the $21^{\text {st }}$ century is not an institution that is supposed to teach how a person should perceive reality and understand it. The times of such a university, which was manifested by the German and English models, changed. Nowadays, the university as an institution is experiencing a crisis. Massification, empowerment and lowering the educational level are suitable adjectives defining today's universities.

The main problem faced by a student at the university is a properly selected course. How can this be achieved? The answer is a very simple — demand in the labour market. The demand for qualified employees has become almost the most important criterion for the selection of studies by contemporary youth. The student today is embroiled in a multifaceted conflict between the university and the labour market. Therefore, often an institution that is a university that should educate the elite of society - in accordance with the idea of an English university — today is only the next level on the career path of a young man. Radosław Rybkowski indicates that a suitably qualified employee, which is associated with holding a degree at a prestigious university, has a much better chance of earning a good than an unpublished student or one who has completed a higher education with the same academic title as the mentioned prestigious university [Rybkowski, 2006: 29].

Well, in addition to the place where you acquire the right skills, it is also important how they will be applied. Today's students want to get involved in searching for the truth. It is important for them that in an easy, effortless way, get the right knowledge that situates them on a particular position in the labour market. Nowadays, the university is treated instrumentally. It means that the basic idea is lost, that is, searching for the truth about various phenomena and things.

Despite such a negative tendency, there are places, that is research universities, such as the California Institute of Technology in Pasadena, the Okinawa Institute of Science and Technology, or even the University of California - Berkeley, where researchers seeking solutions to various problems cooperate together for a specific purpose. However, if these places, these institutions, function in accordance with the spirit of the idea of a traditional university, whose precursors were Wilhelm von Humboldt or John Newman? Have they not been absorbed too much by the commercial mechanisms of the modern world? Is the idea of Newman's "gentleman" still valid and attractive in today's reality? Answers to these questions depend on how modern society will react to changing trends in the university's environment.

\section{Conclusions}

In the summary of this article the Teaching Excellence Summit, co-organized by the Times Higher Education, will take place from 10-12 July 2018 at the University of Glasgow. In the context of the above considerations, this initiative is a perfect exemplification of a process that aims to show the solution to the problem of universities leaving the main idea of seeking truth and educating society.

The importance of the meeting was evidenced by the fact that one of the organizers of this undertaking was Times Higher Education - the best-known magazine devoted to universities around the world [Rybkowski et al., 2018].

Phil Baty, editor-in-chief of Times Higher Education in his speech pointed out that the problem of lowering the level of education applies to all universities, including the group of the most prestigious ones in the highest places in the ranking of the best universities. He also pointed to the fact that politicians in their decisions more and more often refer to the 
achievements of universities, which contributes to increasing the prestige of a given state on the international arena [Rybkowski et al., 2018].

In turn, Anton Muscatelli, the Vice-Chancellor of the University of Glasgow, during his speech emphasized the role of the research and teaching process, and in particular pointed to the challenge faced by today's universities by equipping students with knowledge, skills and perseverance that give them the opportunity to find themselves in contemporary reality, saturated with a lot of information.

The participants of the conference were also Professor Richard Arum, mentioned in this article. In addition to recalling his research on lowering the involvement of American college students in the learning process, he also pointed to the negative trend associated with this phenomenon. It concerned the fact that today universities do not prepare for independent, critical thinking and do not prepare future citizens involved in the life of the country, responsible for shaping democracy [Rybkowski et al., 2018].

During the Teaching Excellence Summit, many other, but not less, interesting issues were raised, such as, for example, the issue of Internet communication with students, presented by Professor Beverly Olivier from Deakin University in Australia.

The main purpose of this conference was to show that the problem related to the quality of teaching is common and you should look for effective solutions that could prevent it. In addition, the conference in Glasgow drew attention to the changing teaching trend under the influence of new technologies. Therefore, universities must focus their attention on the education of a new teaching philosophy, which will be based on new technologies that are an inseparable element of modernity. Finally, the final chord of the Teaching Excellence Summit was an indication that despite the fact that most university funds come from tuition fees, the state plays an important role in the process of both organizational and educational processes [Rybkowski et al., 2018].

In summary, it is worth considering whether today we still have to do with the idea, or even to say, "the spirit of the university"? Taking into account all the above-mentioned facts, the idea of the Humboldtian and Newman's university has been forgotten. The basic assumptions of Wilhelm von Humboldt regarding the university as a research and teaching institution were replaced with the criterion of market pragmatism and connections with the political sphere. In turn, John Newman's "gentleman" took on the form of a philistine, which the intellect uses instrumentally, elevating it beyond the sphere of moral values.

That is why there are many answers to the question of what a modern university is like. However, it certainly is not the same as it was from several decades ago. What are the results of this process, certainly everyone will find out personally?

\section{[ㅁ] References}

Arum, Richard and Josipa Roksa. Academically Adrift. Limited Learning on College Campuses. Chicago, 2011.

Black, Max. Models and Metaphors. New York, 1962.

Bloom, Alan. Umyst zamknięty. O tym, jak amerykańskie szkolnictwo wyższe zawiodło demokrację i zubożyło duszę dzisiejszych studentów. Poznań, 1997.

Brockman, John. Powstaje trzecia kultura. Trzecia kultura, ed. by J. Brockman. Warszawa, 1996: 15-36.

Collini, Stefan. What are Universities For? London, 2012. 
Czeżowski, Tadeusz. O uniwersytecie i studiach uniwersyteckich. Toruń, 1946.

Feyerabend, Paul. Przeciw metodzie. Wrocław, 1996.

Foucault, Michel. Filozofia. Historia. Polityka. Warszawa, 2000.

Jabłecka, Julita. Misja organizacji a misja uniwersytetu. Nauka i Szkolnictwo Wyższe, 2(16), 2000: 7-25.

Kobylarek, Aleksander. Uniwersytet — zarys ewolucji idei podstawowej. Nauka i Szkolnictwo Wyższe, 1(19), 2002: 90-100.

Kwiek, Marek. Uniwersytet $w$ dobie przemian. Instytucje i kadra akademicka $w$ warunkach rosnacej konkurencji, Warszawa 2015: 145-211.

Miłek, Łukasz. Intelekt czy umiejętności? Spojrzenie Johna Henry’ego Newmana na uniwersytet. Kultura i Polityka, No. 5, 2009: 59-72.

Newman, John H. Idea uniwersytetu. Warszawa, 1990.

Rowiński, Paweł, Burczyński, Tadeusz, Duszyński, Jerzy and Andrzej Rychard. Uniwersytet badawczy, czyli...? http://www.pan.poznan.pl/doc/Uniwersytet_badawczy_artukul_ Nauka.pdf

Rybkowski, Radosław. Dlaczego musimy bronić jakości nauczania, https://prenumeruj. forumakademickie.pl/fa/2018/09/kronika-wydarzen/dlaczego-musimy-bronic-jakoscinauczania/

Rybkowski, Radosław. Rola ogólnego wykształcenia wyższego w społeczeństwie wiedzy przykład Stanów Zjednoczonych. Nauka i Szkolnictwo Wyższe, 2(28), 2006: 27-33.

Sauerland, Karol. Idea uniwersytetu - aktualność tradycji Humboldta? Nauka i Szkolnictwo Wyższe, 2(28), 2006: 89-97.

Shumar, Wesley and Sarah Robinson. Universities as Societal Drivers: Entrepreneurial Interventions for a Better Future. The Thinking University. A Philosophical Examination of Thought and Higher Education, ed. by S. Bengsten, R. Barnett, London 2018: 31-47.

Simmel, Georg. O istocie rozumienia historycznego. Wokót rozumienia. Studia i szkice z hermeneutyki, ed. by G. Sowiński. Kraków, 1993: 143-161.

Snow, Charles P. The Two Cultures and the Scientific Revolution, Cambridge 1959.

Standish, Paul. Teaching at the University the Day After Tomorrow. The Future University. Ideas and Possibilities, ed. by R. Barnett. New York, 2012: 152-165.

Taylor, Barrett, Barringer, Sondra and Jarrett Warshaw. Affiliated Nonprofit Organizations: Strategic Action and Research Universities. The Journal of Higher Education, Vol. 89, 2018: 422-452.

Zakowicz, Ilona. Idea Uniwersytetu Wilhelma von Humboldta - kontynuacja czy zmierzch? Ogrody Nauk i Sztuk, No. 2, 2012: 62-74. 